\title{
Use of a commercial PCR kit for detecting Chlamydia trachomatis
}

\author{
I W Smith, C L Morrison, C Patrizio, A McMillan
}

\begin{abstract}
Aims-To evaluate a commercial polymerase chain reaction (PCR) kit for the detection of Chlamydia trachomatis. Methods-Two hundred and fifty seven genital specimens, which had been submitted in 2SP medium for chlamydial isolation and subsequently stored at $-70^{\circ} \mathrm{C}$, were retrospectively examined by a commercial PCR kit which detects chlamydial plasmid DNA. Culture negative, PCR positive specimens were examined by immunofluorescence and an in-house major outer membrane protein (MOMP)-PCR.
\end{abstract}

Results-All 49 specimens which were culture positive were also PCR positive. Another 14 specimens were also PCR positive. After resolution of these results by immunofluorescence and a PCR assay for MOMP the sensitivity for PCR was $98.4 \%$ and that of culture $79 \%$. The specificities were $99.5 \%$ and $100 \%$, respectively.

Conclusions-This kit, which is highly sensitive and specific, is straightforward to use and has a built-in safeguard against cross contamination. The role of this test in the examination of routine genital specimens from patients with uncomplicated chlamydial infection is questionable due to its expense. It may have a place in the investigation of trachoma or infertility, however, where it has been shown that DNA can be detected when culture is unsuccessful.

(F Clin Pathol 1993;46:822-825)

Chlamydia trachomatis is the commonest cause of urethritis in Edinburgh, being seven times more common than gonorrhoea. Gonococcal urethritis declined from 58 to 10 per 100000 men between $1984-1987^{1}$; the incidence of chlamydial urethritis has levelled out or is rising slightly. Although they can be symptomless, especially in women, chlamydial infections can produce salpingitis with subsequent infertility and an increased risk of ectopic pregnancy. In men, especially those under 35 years of age, the infection can also cause epididymitis. Neonates are also at risk of infection from infected parents. ${ }^{2}$ As the infection is amenable to antibiotic treatment it is important to identify infected patients and their partners to eradicate infection. - Various methods have been used to detect the presence of chlamydia but none is ideal. ${ }^{34}$ Cell culture detects viable organisms but requires special transport and storage of specimens; antigen detection by immunofluorescence is subjective, requiring expertise to interpret the smears, and antigen detection by ELISA, though objective, can give rise to false positive results due to cross-reactions with other micro-organisms unless confirmatory tests are carried out. Polymerase chain reaction (PCR) has been used in research and seems to be both sensitive and specific: commercial kits are now being developed for the amplification and detection of chlamydiae. A PCR kit manufactured by Roche has been applied to stored culture specimens in a diagnostic laboratory.

\section{Methods}

Two hundred and fifty seven genital specimens (from 157 women and 100 men) were submitted in 2SP transport medium for chlamydial culture and stored at $-70^{\circ} \mathrm{C}$. Of these, $49(19 \cdot 8 \%)$ were culture positive (27 from women, 22 from men). Culture had been carried out in McCoy cells in the presence of cycloheximide, ${ }^{5}$ but had been incubated for 72 hours before being stained with iodine to demonstrate the presence of glycogen containing inclusions. ${ }^{6}$

\section{POLYMERASE CHAIN REACTION}

Roche plasmid amplification for 2SP specimens The kits were kindly supplied by Roche Diagnostic Systems. All specimens were tested at 1 in 20 dilution and those which were negative were subsequently tested at 1 in 10 to detect any weakly positive reactions. Ten or $20 \mu \mathrm{l}$ of specimen were transferred to either 190 or $180 \mu \mathrm{l}$ of Amplicor specimen transport medium (STM), giving a 1 in 20 or 1 in 10 dilution. After vortexing in capped tubes the suspension was held at room temperature for 5-10 minutes. Amplicor STD specimen diluent $(200 \mu \mathrm{l})$ was added to this suspension, again vortexed and left $10 \mathrm{~min}$ utes at room temperature before use.

The amplification of the DNA was carried out according to the manufacturer's instructions. Briefly, $50 \mu \mathrm{l}$ of prepared sample, positive or negative control (in triplicate), was added to $50 \mu$ l of Master Mix plus Amperase (uracil-N-glycosylase) and subjected to 30 cycles of amplification in a Perkin-Elmer Cetus Gene Amplifier PCR System, 9600 thermal cycler. As the Master Mix contained biotinylated primers the resulting product 
Table 1 Laboratory and clinical findings on PCR negative culture patients

\begin{tabular}{|c|c|c|c|c|c|}
\hline $\begin{array}{l}\text { Case } \\
\text { No }\end{array}$ & $\operatorname{Sex}$ & Roche PCR (1 in 20) & Immunofluorescence & Chromosome PCR & Clinical presentation \\
\hline 1 & F & $1 \cdot 227$ & $\begin{array}{l}<10 \\
\text { Elementary } \\
\text { bodies }\end{array}$ & + & $\begin{array}{l}\text { Asymptomatic: no evidence } \\
\text { of chlamydial infection }\end{array}$ \\
\hline 2 & $\mathrm{~F}$ & $>2 \cdot 00$ & + & ND & $\begin{array}{l}\text { Genital warts: no evidence of } \\
\text { chlamydial infection culture } \\
+3 \text { weeks later }\end{array}$ \\
\hline 3 & $\mathbf{F}$ & $>2 \cdot 00$ & $\begin{array}{l}<10 \\
\text { Elementary } \\
\text { bodies }\end{array}$ & + & $\begin{array}{l}\text { Genital warts: mucopus at } \\
\text { cervix Culture }+4 \\
\text { months later }\end{array}$ \\
\hline 4 & $\mathbf{F}$ & $>2.00$ & + & ND & $\begin{array}{l}\text { Vaginal discharge: no evidence } \\
\text { of chlamydial infection }\end{array}$ \\
\hline 5 & $\mathbf{M}$ & $>2 \cdot 00$ & + & ND & NSG1 \\
\hline 6 & $\mathbf{M}$ & $\begin{array}{l}>2.00 \\
>2.00\end{array}$ & + & ND & NSG1 \\
\hline $\begin{array}{l}7 \\
8\end{array}$ & $\begin{array}{l}\mathbf{M} \\
\mathbf{M}\end{array}$ & $\begin{array}{l}>2 \cdot 00 \\
>2 \cdot 00\end{array}$ & $\begin{array}{l}+ \\
+\end{array}$ & $\begin{array}{l}+ \\
+\end{array}$ & $\begin{array}{l}\text { NSG1 } \\
\text { Asymptomatic: contact of } \\
\text { chlamydia infected female }\end{array}$ \\
\hline 9 & $\mathbf{M}$ & $>2 \cdot 00$ & + & + & NSG1: had NSU 1988 \\
\hline 10 & $\mathbf{F}$ & $>2 \cdot 00$ & - & + & $\begin{array}{l}\text { NSG1: ELISA positive } 9 \text { months } \\
\text { ago Boyfriend not treated until } \\
8 \text { months later }\end{array}$ \\
\hline 11 & $\mathbf{F}$ & $>2 \cdot 00$ & $\begin{array}{l}<10 \\
\text { Elementary } \\
\text { bodies }\end{array}$ & NA & $\begin{array}{l}\text { NSG1: culture positive } 7 \text { months } \\
\text { and } 12 \text { months ago } \\
\text { Partially treated } 7 \text { months ago }\end{array}$ \\
\hline 12 & $\mathrm{~F}$ & 0.982 & - & + & $\begin{array}{l}\text { ELISA positive } 11 \text { days ago: } \\
\text { not treated at that time }\end{array}$ \\
\hline 13 & $\mathbf{F}$ & $>2 \cdot 00$ & + & ND & $\begin{array}{l}\text { ELISA positive } 10 \text { days ago: } \\
\text { not treated at that time }\end{array}$ \\
\hline 14 & $\mathbf{F}$ & $1 \cdot 094(1: 10)$ & - & - & $\begin{array}{l}\text { Vaginal discharge No } \\
\text { evidence of chlamydial infection }\end{array}$ \\
\hline
\end{tabular}

ND not done; NA not available; NSG1 non-specific genital tract infection.

was biotinylated and was denatured by adding $100 \mu \mathrm{l}$ denaturation solution for 10 minutes at room temperature.

The presence of any biotinylated amplified DNA was detected according to manufacturer's instructions. The labelled product was captured on the probe coated plate by allowing $25 \mu \mathrm{l}$ of sample or control to interact with the plate for 1 hour at $37^{\circ} \mathrm{C}$ in a moist box. The plate was carefully washed with Roche wash buffer, $300 \mu$ l being added to each well for 30 seconds, on each of five occasions. Avidin-horseradish peroxidase conjugate (100 $\mu$ l) was added to each well for 15 minutes at $37^{\circ} \mathrm{C}$. After washing as above, $100 \mu \mathrm{l}$ of tetramethylbenzidine-peroxide substrate was added, the plate incubated at room temperature for 10 minutes in the dark, and the reaction stopped by the addition of $100 \mu \mathrm{l}$ stop reagent before reading the results at $450 \mathrm{~A} .^{7}$ An optical density of 0.25 or over was taken as positive provided the positive and negative controls fell within the correct limits.

\section{In-house MOMP amplification}

2SP specimen $(100 \mu \mathrm{l})$ was spun in the wind shielded Biofuge 15000 at $13000 \mathrm{rpm}$ for 10 minutes. The resulting pellet was extracted, amplified using nested primers, and the amplicon detected by ethidium bromide staining of an agarose electrophoresis gel following the method of Simmonds et al. ${ }^{8}$ Briefly, the DNA was phenol-chloroform

Table 2 Comparison of PCR and culture with total resolved specimens

\begin{tabular}{|c|c|c|c|c|}
\hline \multirow[b]{2}{*}{ Test and result } & \multicolumn{2}{|c|}{ No of resolved specimens } & \multirow{2}{*}{$\begin{array}{l}\text { Sensitivity } \\
(\%)\end{array}$} & \multirow{2}{*}{$\begin{array}{l}\text { Specificity } \\
(\%)\end{array}$} \\
\hline & Positive & Negative & & \\
\hline \multicolumn{5}{|l|}{ PCR } \\
\hline Positive & 62 & 1 & $98 \cdot 4$ & \\
\hline Negative & 0 & 194 & & $99 \cdot 5$ \\
\hline \multicolumn{5}{|l|}{$\begin{array}{l}\text { Culture } \\
\text { Con }\end{array}$} \\
\hline Positive & 49 & 0 & 79 & \\
\hline Negative & 13 & 195 & & 100 \\
\hline
\end{tabular}

extracted, the amplification carried out on a Techne PHC-2 machine with a programme of $94^{\circ} \mathrm{C}$ for 36 seconds, $50^{\circ} \mathrm{C}$ for 42 seconds, $68^{\circ} \mathrm{C}$ for 3 minutes for 25 cycles, and $68^{\circ} \mathrm{C}$ for 5 minutes to complete the strands. The outer nested primers were $420 \mathrm{M}$ (sense) 5 ' CAG GA c/t ATC TTC TCT GGC TTT AA3' and 423M (antisense) 5' $\mathrm{CGg} / \mathrm{c}$ ATG CTg/a ATA GCG TCA CAC CAA GT 3', and the inner ones which gave a product of 109 base pairs were CT3 (sense) and CT2 (antisense) (Dutilth et al). ${ }^{9}$ All the primers were produced by Oswel DNA Service, Department of Chemistry, University of Edinburgh.

\section{IMMUNOFLUORESCENCE}

Preparations were prepared by depositing material from $150 \mu \mathrm{l}$ of $2 \mathrm{SP}$ specimen in a wind shielded Biofuge 15000 at $15000 \mathrm{rpm}$ for 15 minutes. The pellet was resuspended in sterile distilled water and 5-10 $\mu \mathrm{l}$ spread on the well of a Teflon coated slide. Alternatively, cytospin preparations were prepared from $150 \mu \mathrm{l}$ of specimen by spinning at $2000 \mathrm{rpm}$ for 10 minutes in a Shandon 3 Cytospin. Both types of preparation were allowed to dry, fixed in methanol for $10 \mathrm{~min}$ utes, and stained by Syva Micro Trak reagent according to the manufacturer's instructions.

\section{Results}

Initially the 2SP specimens were spun down and resuspended in specimen diluent. One hundred and eighty were PCR negative and as they were also culture negative the results were accepted and the specimens subsequently discarded. The remainder of the specimens, some of which were discrepant, were retested, as discussed in methods section. Fourteen had an optical density reading of $0.077-0.172$ at $a 1$ in 10 dilution and $0.058-0.211$ at $\mathrm{a} 1$ in 20 dilution, and so 
were considered PCR negative. These 14 specimens were all culture and immunofluorescence negative and the 11 available were MOMP PCR negative, so they were considered to be resolved negative results. The initial "positive" results were thought to be due to excess magnesium in the reaction mixture because the specimen diluent, which is the source of magnesium, was effectively at double strength (Dr E Dragon, personal communication). Sixty three samples had an optical density of $0.978 \rightarrow 2.0$ (only six being below $2 \cdot 0$ ), so were PCR positive, confirming the culture results in 49 instances.

The 14 Roche PCR positive, culture negative specimens were also examined by immunofluorescence, in-house PCR, and the clinical presentation recorded (table 1 ). In all but specimen 11 the Roche PCR was confirmed by either more than 10 elementary bodies or in-house PCR, or both. There was insufficient specimen 11 to carry out an inhouse PCR and less than 10 elementary bodies were present in the immunofluorescence preparation. Compared with specimens 1 and 3, however, it seemed likely that the Roche PCR result was confirmed and specimen 11 has been regarded as resolved. Specimen 14 yielded an optical density of 1.094 in the Roche PCR, but did not have any elementary bodies in the immunoflourescence preparation, and was negative by the in-house PCR test, so it was considered to be an unconfirmed Roche PCR.

The comparison of the PCR and culture with total $(n=257)$ resolved specimens is shown in table 2 where the sensitivity of PCR is $98.4 \%$ and culture $79 \%$ and specificity $99.5 \%$ and $100 \%$, respectively.

\section{Discussion}

As the chlamydia isolation rate is about $8 \%$ in the specimens received in this laboratory it was decided to use stored specimens which had been cultured before. In the absence of a method for testing 2SP specimens, unwittingly, double the concentration of magnesium was incorporated in the amplification mixture, resulting in 14 "positives". These results disagree with those of culture, immunofluorescence, in-house MOMP-PCR and clinical observations. When, however, these 14 specimens were retested using the correct reaction mixture, they were all negative, indicating that the method described here must be used for 2SP specimens.

Loeffelholz et $a l^{7}$ reported on the development of the Roche PCR used here. They examined duplicate (2SP and STM) endocervical specimens from 503 women attending a clinic where the incidence of $C$ trachomatis was $17 \%$ at the time of study. The culture sensitivity against total resolved specimens was $85.6 \%$ compared with $97.0 \%$ for PCR. The specificities were $100 \%$ and $99 \cdot 7 \%$, respectively. In this study two fifths of the 257 patients were men and only stored 2SP specimens were available. The culture sensitivity was $79 \%$ compared with $98.4 \%$ for
PCR with specificities of 100 and $99.5 \%$, respectively. These results were very similar and showed that the Roche kit could be applied to both male and female specimens. The level of culture sensitivity is just below the published $80-90 \% .^{10}$ The lower sensitivity of the culture found here might have been influenced by the fact that the specimens were neither blind passaged nor confirmed by immunofluorescence. The results do, however, compare favourably with those of Ossewarde et al, ${ }^{11}$ whose 220 patients were predominantly male, and who found that with a different plasmid PCR the culture and PCR sensitivity with reference to confirmed PCR was $72.3 \%$ and $100 \%$, with specificities of $98.8 \%$ and $98.3 \%$, respectively.

The issue of clinical importance of PCR positivity in the absence of culture has been raised by the previous authors ${ }^{11}$ and Näher et $a l^{12}$ whose culture sensitivity against unresolved plasmid PCR was $65 \%$. C trachomatis has been isolated from asymptomatic male and female patients, ${ }^{1314}$ and in this series eight of the 49 culture positive patients were classified as asymptomatic. Only one of the 14 PCR positive, culture negative patients was asymptomatic, all the others had evidence of sexually transmitted disease or were a contact of a patient with a chlamydial infection. One of the patients with condylomata had a swab taken at follow up three weeks later and this was culture positive so the index specimen was either false culture negative or the infection was in its very early stage. ${ }^{15}$ Certainly, very few elementary bodies were observed. Five of the patients had a history of chlamydial infection, two in the previous 10-11 days. These patients were treated on day 10 and 11 on the basis of the confirmed ELISA positive result and were culture negative (one also PCR negative) at test of cure. It would therefore seem logical to treat PCR positive, culture negative patients and to undertake contact tracing.

Another reason for treating PCR positive, culture negative patients is evident from experimental work with monkeys. ${ }^{16}$ After ocular infection chlamydia could be detected by PCR for up to five weeks longer than culture. Because RNA was also present, it was thought that the organism was "live" but was incapable of replication, perhaps due to the presence of a cytokine.

In such cases test of cure should be done on follow up to ensure that they were PCR negative. This would detect treatment failure in patients with non-replicating chlamydia. Bobo et $\mathrm{al}^{17}$ found that nine of 112 PCR positive "culture-not-done" patients with trachoma were still PCR positive after four weeks of treatment. These patients are being followed up as they could be non-compliers or they may be refractory to treatment and continue to be a source of chlamydia. Claas et $a l^{18}$ found that the tests of cure of culture positive patients were PCR negative, and so considered that the organism had been eliminated, but Ossewaarde et $a l^{19}$ found that two of their 29 patients still had evidence of 
chlamydial DNA by PCR four weeks after treatment despite compliance and refraining from sexual intercourse.

As PCR is such an extremely sensitive assay problems can arise from possible contamination of new specimens with previously amplified DNA. In an attempt to obviate this problem the specimens here were handled according to local practice: the 2SP specimens were extracted in a hood in one laboratory, the amplification mixture prepared in a hood in another laboratory, and the amplification and detection carried out in a third laboratory. For the Roche PCR these precautions may not have to be so stringent because the amplicons incorporate uracil instead of thymidine and so can be distinguished from any chlamydia DNA. Uracil-N-glycosylase (UNG), which is incorporated in the amplification mixture, will degrade any contaminating amplicon during the first high temperature phase of amplification leaving only true chlamydia DNA to be copied. The UNG itself is denatured at the end of the reaction allowing the new amplicon to remain intact and be detected. This added feature enhances the use of the technique in a routine diagnostic laboratory with limited space.

The Roche PCR kit, which is highly sensitive and specific $\left(99 \cdot 7 \%,{ }^{7} 99.5 \%\right.$ in this study) is very straightforward to use and has the built-in safeguard mentioned above. The main problems are (a) the expense for a routine diagnostic laboratory and (b) the lack of complete correlation with culture for medicolegal purposes. A role could possibly be found for it in the investigation of patients with salpingitis or infertility. In patients with trachoma ${ }^{20}$ and infertility ${ }^{21}$ it has been possible to detect DNA by in situ hybridisation when culture was unsuccessful. Similarly, in experimental monkeys the DNA could still be detected by PCR in the absence of culture so results of PCR investigations on infertile women, be they positive or negative, could be of value in their future management.

1 Ross JDC, Scott GR. Seasonal variation in gonorrhea. Eur ₹ Epidemiol 1992;8:252-6.

2 Treharne JD, Ballard RC. The expanding spectrum of the Chlamydia-a microbiological and clinical appraisal. Rev Med Microbiol 1990;1:10-18.

3 Ridgway GL, Taylor-Robinson D. Current problems in microbiology: 1 Chlamydial infections: which laboratory test? $f$ Clin Pathol 1991;44:1-5.

4 Taylor-Robinson D, Thomas BJ. Laboratory techniques for the diagnosis of chlamydial infections. Genitourin Med 1991;67:256-66.

5 Thomas BJ, Evans RT, Hutchinson GR, Taylor-Robinson $D$. Early detection of Chlamydia inclusions combining the use of cycloheximide treated McCoy cells and immunofluorescence staining. F Clin Microbiol 1977;6: 285-92.

6 Evans RT, Woodland RM. Detection of chlamydiae by isolation and direct examination. Br Med Bull 1983; 39:181-6.

7 Loeffelholz MJ, Lewinski CA, Silver SR, et al. Detection of Chlamydia trachomatis in endocervical specimens by polymerase chain reaction. $\mathcal{f}$ Clin Microbiol 1992;30: 2847-51.

8 Simmonds P, Balfe P, Peutherer JF, Ludlam CA, Bishop JO, Leigh Brown AJ. Human immunodeficiency virusinfected individuals contain provirus in small numbers of peripheral mononuclear cells and at low copy numbers. F Virol 1990;64:864-72.

9 Dutilth B. Bébéar C, Rodriguez P, Vekris A, Bennet J, Garnet M. Specific amplification of a DNA sequence common to all Chlamydia trachomatis serovars using common to all Chlamydia trachomatis serovars using
the polymerase chain reaction. Res Microbiol the polymerase

10 Mahony JB, Luinstra KE, Sellors JW, Jang D, Chernesky MA. Confirmatory polymerase chain reaction testing for Chlamydia trachomatis in first-void urine from asymptomatic and symptomatic men. $\mathcal{F}$ Clin Microbiol 1992;30: 2241-5.

11 Ossewaarde JM, Rieffe $M$, Rozenberg-Arksa $M$, Ossenkoppele PM, Nawrocki RP, van Loon AM Development and clinical evaluation of a polymerase chain reaction test for detection of Chlamydia trachomatis. $\mathcal{F}$ Clin Microbiol 1992;30:2122-8.

12 Näher H, Drzonek H, Wolf J, von Knebel Doeberitz $M$ Petzoldt D. Detection of $C$, von Knebel Doeberitz $M$, Petzoldt $D$. Detection of $C$ trachomatis in urogenital 1991;67:211-4.

13 Hunter JM, Smith IW, Peutherer JF, MacAulay A, Tuach $S$, Young $\mathrm{H}$. Chlamydia trachomatis and Ureaplasma urealyticum in men attending a sexually transmitted diseases clinic. Br $\mathcal{F}$ Vener Dis 1981;57:130-3.

14 Hunter JM, Smith IW, Peutherer JF, MacAulay AJ. Chlamydia trachomatis infection of the cervix: the need for a diagnostic service. Scot Med f 1982;27:147-51.

15 Ostergaard L, Traulsen J, Birkelund S, Christiansen G. Evaluation of urogenital Chlamydia trachomatis infections by cell culture and the polymerase chain reaction using a closed system. Eur $\mathscr{f}$ Clin Microbiol Infect Dis using a closed sy

16 Holland SM, Hudson AP, Bobo L, et al. Demonstration of chlamydial RNA and DNA during a culture-negative state. Infect Immunol 1992;60:2040-7.

17 Bobo L, Munoz B, Viscidi R, Quinn T, Mkocha H, West $S$. Diagnosis of Chlamydia trachomatis eye infection in Tanzania by polymerase chain reaction/enzyme mmunoassay. Lancet 1991;338:847-50.

18 Claas HCJ, Wagenvoort JHT, Niesters HGM, Tio TT, van Rijsoort-Vos JH, Quint WGV. Diagnostic value of the polymerase chain reaction for Chlamydia detection the polymine in a follow-up study. $f$ Clin Microbiol 1991;29:42-5.

19 Ossewaarde JM, Plantema FHF, Rieffe M, Nawrocki RP, de Vries A, van Loon AM. Efficacy of single-dose de Vries A, van Loon AM. Efficacy of single-dose azithromycin versus doxycycline in the treatment of cervical infections caused by Chlamydia
Clin Microbiol Infect Dis 1992;8:693-7.

20 Schachter J, Moncada J, Dawson CR, et al. Nonculture methods for diagnosing chlamydial infection in patients with trachoma: a clue to the pathogenesis of the disease? f Infect Dis 1988;158:1347-52.

21 Campbell LA, Patton DL, Moore DE, Cappuccio AL, Mueller BA, Wang S. Detection of Chlamydia trachomatis deoxyribonucleic acid in women with tubal infertility. Fertil Steril 1993;59:45-50. 